\title{
Maximum Cell Density
}

National Cancer Institute

\section{Source}

National Cancer Institute. Maximum Cell Density. NCI Thesaurus. Code C120710.

The maximum value in a range of values that describe cell density. 